\title{
Periconceptional vitamin supplementation and the prevention of neural tube defects in south-east England and Northern Ireland
}

\author{
MARY J SELLER AND NORMAN C NEVIN \\ From the Paediatric Research Unit, Guy's Hospital Medical School, London SE1 9RT; and Medical Genetics \\ Department, Institute of Clinical Science, Grosvenor Road, Belfast BT12 6BJ.
}

SUMMARY A comparison has been made of the effectiveness of periconceptional vitamin supplementation for the prevention of recurrence of neural tube defects (NTD) in south-east England and Northern Ireland. These areas represent the extremes of birth prevalence of NTD (low and high respectively) within the United Kingdom. Vitamin therapy resulted in a slightly less than two-fold reduction in the recurrence risk in south-east England and a greater than three-fold reduction in Northern Ireland, when compared with unsupplemented women at the same risk from the two areas. It is probable that one of the recurrences in each area did not involve the multifactorial form of NTD and, if these are excluded, then the reduction in recurrence risk with vitamin supplementation is 2.4 times in south-east England and 5.4 times in Northern Ireland. Either way, beneficial effects of supplementation are apparent in both areas but are more marked in the high prevalence area. The implications of this for the future are discussed. Two other important findings were that all but one of the recurrences of NTD with full supplementation occurred in male fetuses, and there was a higher than expected occurrence of isolated hydrocephalus in infants or fetuses following full supplementation.

The periconceptional vitamin supplementation study for the prevention of neural tube defects (NTD) has now published two separate, but continuous, cohorts, documenting 454 fully supplemented pregnancies. ${ }^{12}$ The combined results have demonstrated a recurrence of $0.7 \%$ (three NTD in the 429 babies or fetuses examined) in fully supplemented women, compared with $4.7 \%$ (24 NTD in 510) in unsupplemented women. These findings have stimulated much interest, which ranges from enthusiasm to scepticism.

This study was a collaborative one involving initially five, and latterly six, centres in the United Kingdom: Leeds, London, Belfast, Manchester, Chester, and Liverpool. Of the total of 454 fully supplemented mothers, 292 (64\%) have come from two of these centres, London and Belfast. The areas from which these two centres draw their patients are of particular interest, because they represent the extremes within the UK regarding birth prevalence of NTD. Northern Ireland and south-east England are high and low prevalence areas, respectively.

Received for publication 20 December 1983. Accepted for publication 14 February 1984.
With a multifactorial disorder involving a geneenvironmental interaction, it is generally considered that, in low prevalence populations, the non-genetic or environmental factor(s) are of less importance in the aetiology than in high prevalence populations. Indeed, Sever $^{3}$ has produced epidemiological evidence that this is so from a study of NTD in Los Angeles County, a low prevalence area. It follows, therefore, that in attempting primary prevention of a multifactorial disorder by manipulating the environmental factor(s), such a measure may be less effective in low than in high prevalence areas.

We therefore thought that it would be useful to compare the effects of periconceptional vitamin supplementation in our two areas to determine if there is a differential effect.

We present the results from the time we entered the trial (1976 for south-east England, 1977 for Northern Ireland) through to conceptions which occurred up to 31 December 1982, all women having now delivered. Thus, some of the results have been included in the two published papers of Smithells et $a l^{12}{ }^{2}$ while the remainder have not yet been published. However, it should be emphasised that 
they all comprise part of the same continuous and continuing study.

\section{Methods}

The methods are as previously published. ${ }^{1}$ In brief, women at risk who are not yet pregnant who wish to participate are asked to take Pregnavite Forte F (Bencard), three tablets daily, for at least 28 days before conception, and for 6 weeks after conception. Those who comply with this are termed fully supplemented (FS). Any who fall short of this regimen are called partially supplemented (PS). Women at risk are those who have had one or more children with the multifactorial form of NTD, such as anencephaly, encephalocele, cranial meningocele, iniencephaly, myelocele, myelomeningocele, and meningocele. Women who had one or more children with NTD owing to a gene or chromosomal abnormality, such as Meckel's syndrome or trisomy 18, were not included. In the part of the work already published, spina bifida occulta was excluded. However, in the subsequent work in south-east England, if there was a previous child with a spina bifida occulta severe enough to manifest itself, it was regarded as part of the NTD spectrum and the mother was supplemented if she wished.

The study area in south-east England included patients from London and Greater London, Kent, Surrey, Sussex, Essex, Hertfordshire, and Suffolk. For Northern Ireland it comprised the whole of the Province.

The supplemented subjects were compared with women at the same risk of recurrence, who lived in the same general area and who conceived at roughly the same time, but who received no supplementation (unsupplemented women, US). These controls were women referred for amniocentesis and were selected before any diagnostic tests had been performed. The unsatisfactory nature of the design of the trial, which resulted because ethical approval was not given for the planned double blind placebo trial, has been discussed exhaustively and will not be considered here.

\section{Results}

There were 219 FS pregnancies and 260 US pregnancies from south-east England, and 246 FS and 311 US pregnancies from Northern Ireland (table 1). Some pregnancies resulted in spontaneous abortions and in many the fetus was not examined, usually because the abortion occurred in the first trimester. These are excluded from the analysis of the results.

In south-east England, in 250 babies or fetuses examined from US patients, there were nine with NTD, a recurrence of one in $28(3 \cdot 6 \%)$. Among the
TABLE 1 Overall recurrence of NTD in unsupplemented women (US) and in women following full periconceptional vitamin supplementation (FS) in SE England and Northern Ireland.

\begin{tabular}{|c|c|c|c|c|}
\hline & \multicolumn{2}{|c|}{$S E$ England } & \multicolumn{2}{|c|}{ Northern Ireland } \\
\hline & US & $F S$ & $U S$ & $F S$ \\
\hline Total pregnancies & 260 & 219 & 311 & 246 \\
\hline No of twins & 4 & 0 & 3 & 1 \\
\hline $\begin{array}{l}\text { Spontaneous abortion: } \\
\text { not examined } \\
\text { Babies/fetuses }\end{array}$ & 14 & 21 & 21 & 21 \\
\hline examined, no NTD & 241 & 194 & 279 & 223 \\
\hline NTD & 9 & 4 & 14 & 3 \\
\hline NTD & 9 & 4 & 14 & 3 \\
\hline Total & $\overrightarrow{250}$ & $\overline{198}$ & 293 & $\overline{226}$ \\
\hline Recurrence & $\begin{array}{l}1 \text { in } 28 \\
(3.6 \%)\end{array}$ & $\begin{array}{l}1 \text { in } 50 \\
(2.0 \%)\end{array}$ & $\begin{array}{l}1 \text { in } 21 \\
(4.8 \%)\end{array}$ & $\begin{array}{l}1 \text { in } 75 \\
(1.3 \%)\end{array}$ \\
\hline
\end{tabular}

198 babies or fetuses examined in the FS group, there were four with NTD, an overall recurrence of one in $50(2 \%)$. In Northern Ireland, there were 293 US babies or fetuses examined, of whom 14 had NTD, an overall recurrence of one in $21(4 \cdot 8 \%)$. Among the 226 babies or fetuses examined in the FS group, three had an NTD, a recurrence of one in $75(1.3 \%)$. If the results are examined according to the number of previous NTD (table 2), in south east England vitamin supplementation has produced a recurrence of one in $85(1.2 \%)$ in women with one previous NTD, and one in $15(6.9 \%)$ for those with two or more. In Northern Ireland, the respective figures are one in $70(1.4 \%)$ and 0 in 17 .

With regard to the reliability of the control figures, two comparisons have been made. For south-east England, the findings of an analysis of recurrence in the Genetics Clinic population attending Guy's Hospital from 1972 to $1979^{4}$ has been used. For Northern Ireland, an analysis has been made of recurrence in women with a previous child

TABLE 2 Recurrence of NTD in women receiving full periconceptional vitamin supplementation in SE England and Northern Ireland according to number of previous NTD.

\begin{tabular}{|c|c|c|c|c|}
\hline & \multicolumn{2}{|l|}{ SE England } & \multicolumn{2}{|c|}{ Northern Ireland } \\
\hline & $\begin{array}{l}1 \text { previous } \\
N T D\end{array}$ & $\begin{array}{l}\geqslant 2 \text { previous } \\
\text { NTD }\end{array}$ & $\begin{array}{l}1 \text { previous } \\
\text { NTD }\end{array}$ & $\begin{array}{l}\geqslant 2 \text { previous } \\
N T D\end{array}$ \\
\hline Total pregnancies & 187 & 32 & 229 & 17 \\
\hline No of twins & 0 & 0 & 1 & 0 \\
\hline \multicolumn{5}{|c|}{ Spontaneous abortion: } \\
\hline not examined & 18 & 3 & 21 & 0 \\
\hline \multicolumn{5}{|l|}{ Babies/fetuses } \\
\hline no NTD & 167 & 27 & 206 & 17 \\
\hline NTD & 2 & 2 & 3 & 0 \\
\hline NTD & 2 & 2 & 3 & 0 \\
\hline Total & $\overline{169}$ & $\overline{29}$ & $\overline{209}$ & $\overline{17}$ \\
\hline Recurrence & $\begin{array}{l}1 \text { in } 85 \\
(1.2 \%)\end{array}$ & $\begin{array}{l}1 \text { in } 15 \\
(6.9 \%)\end{array}$ & $\begin{array}{l}1 \text { in } 70 \\
(1.4 \%)\end{array}$ & 0 in 17 \\
\hline
\end{tabular}


with an NTD undergoing amniocentesis during the period 1973 to 1981 (N C Nevin, unpublished data). In both cases, the recurrence rates in these populations are very similar to those occurring in the respective control groups of the Vitamin Study (table 3) and different from those of the supplemented women.

Major congenital abnormalities other than NTD are given in table 4. In south-east England, the prevalence was $2 \%$ in both the US and FS groups, five out of 250 babies or fetuses examined and four of 198, respectively. In Northern Ireland it was $1.7 \%$ (five of 293 ) in US women and $2.2 \%$ (five of 226 ) in the FS group. Thus, there was no excess in the supplemented groups. No unexpected malformations occurred either, but there were three cases of hydrocephalus among the FS group. Table 5 gives the supplementation history and other details of these three cases. Patient 2 appears to be different from the other cases. There was one hydrocephalic infant in the unsupplemented women.

Similar information is given for the women who had recurrences of NTD despite full supplementation (table 6). They all appear to have been adequately supplemented, and there is no reason to believe that they did not take their tablets. It must be noted that

TABLE 3 Recurrences of NTD in women receiving full periconceptional vitamin supplementation according to number of previous NTD compared with two sets of unsupplemented controls.

\begin{tabular}{|c|c|c|c|c|c|c|}
\hline & \multicolumn{2}{|c|}{ Overall } & \multicolumn{2}{|c|}{1 previous $N T D$} & \multicolumn{2}{|c|}{2 previous $N T D$} \\
\hline & $\frac{N T D}{\text { Total }}$ & Recurrence & $\frac{N T D}{\text { Total }}$ & Recurrence & $\frac{N T D}{\text { Total }}$ & Recurrence \\
\hline $\begin{array}{l}\text { SE England } \\
\text { Genetics clinic population 1972-19794 }\end{array}$ & $\frac{33}{958}$ & $\begin{array}{l}1 \text { in } 29 \\
3.4 \%\end{array}$ & $\frac{29}{920}$ & $\begin{array}{l}1 \text { in } 32 \\
3.2 \%\end{array}$ & $\frac{4}{38}$ & $\begin{array}{l}1 \text { in } 9 \\
10.5 \%\end{array}$ \\
\hline Controls to Vitamin Study 1976-1982 & $\frac{9}{250}$ & $\begin{array}{l}1 \text { in } 28 \\
3.6 \%\end{array}$ & $\frac{6}{229}$ & $\begin{array}{l}1 \text { in } 38 \\
2.6 \%\end{array}$ & $\frac{3}{21}$ & $\begin{array}{l}1 \text { in } 7 \\
14 \cdot 3 \%\end{array}$ \\
\hline Full vitamin supplementation 1976-1982 & $\frac{4}{198}$ & $\begin{array}{l}1 \text { in } 50 \\
2.0 \%\end{array}$ & $\frac{2}{169}$ & $\begin{array}{l}1 \text { in } 85 \\
1.2 \%\end{array}$ & $\frac{2}{29}$ & $\begin{array}{l}1 \text { in } 15 \\
6.9 \%\end{array}$ \\
\hline Northern Ireland & & & & & & \\
\hline $\begin{array}{l}\text { Amniocentesis population 1973-1981 } \\
\text { (N C Nevin, unpublished data) }\end{array}$ & $\frac{43}{1012}$ & $\begin{array}{l}1 \text { in } 23 \\
4.2 \%\end{array}$ & $\frac{35}{916}$ & $\begin{array}{l}1 \text { in } 26 \\
3 \cdot 8 \%\end{array}$ & $\frac{8}{96}$ & $\begin{array}{l}1 \text { in } 12 \\
8.3 \%\end{array}$ \\
\hline Controls to Vitamin Study 1977-1982 & $\frac{14}{293}$ & $\begin{array}{l}1 \text { in } 21 \\
4.8 \%\end{array}$ & $\frac{13}{264}$ & $\begin{array}{l}1 \text { in } 20 \\
4.9 \%\end{array}$ & $\frac{1}{29}$ & $\begin{array}{l}1 \text { in } 29 \\
3.4 \%\end{array}$ \\
\hline Full vitamin supplementation 1977-1982 & $\frac{3}{226}$ & $\begin{array}{l}1 \text { in } 75 \\
1 \cdot 3 \%\end{array}$ & $\frac{3}{209}$ & $\begin{array}{l}1 \text { in } 70 \\
1.4 \%\end{array}$ & $\frac{0}{17}$ & $\underline{0}$ in 17 \\
\hline
\end{tabular}

TABLE 4 Major abnormalities other than NTD in offspring of women in study in SE England and Northern Ireland.

\begin{tabular}{|c|c|c|}
\hline & $S E$ England & Northern Ireland \\
\hline $\begin{array}{l}\text { Unsupplemented } \\
\text { No of babies/fetuses examined } \\
\text { No of abnormalities excluding NTD } \\
\text { Prevalence (\%) } \\
\text { Details of abnormalities }\end{array}$ & $\begin{array}{l}250 \\
5 \\
2 \cdot 0 \% \\
1 \text { congenital dislocation of hips } \\
1 \text { bowel obstruction (NND) } \\
1 \text { congenital cataract } \\
1 \text { cleft lip } \\
1 \text { cervical cystic hygromata and } \\
\quad \text { arthrogryposis (male) }\end{array}$ & $\begin{array}{l}293 \\
5 \\
1 \cdot 7 \% \\
1 \text { tracheal atresia, imperforate anus } \\
1 \text { trisomy } 21 \text { Down's syndrome } \\
1 \text { hydrocephalus } \\
1 \text { fusion of lumbar vertebrae and } \\
\text { hemivertebrae } \\
1 \text { cleft lip }\end{array}$ \\
\hline $\begin{array}{l}\text { Full vitamin supplementation } \\
\text { No of babies/fetuses examined } \\
\text { No of abnormalities excluding NTD } \\
\text { Prevalence (\%) } \\
\text { Details of abnormalities }\end{array}$ & $\begin{array}{l}198 \\
4 \\
2 \cdot 0 \% \\
1 \text { L renal agenesis + anal atresia } \\
1 \text { congenital heart defect } \\
2 \text { hydrocephalus }\end{array}$ & $\begin{array}{l}226 \\
5 \\
2 \cdot 2 \% \\
1 \text { hydrocephalus } \\
1 \text { true hermaphrodite and cleft palate } \\
1 \text { bilateral inguinal hernia, umbilical hernia, } \\
\text { and bilateral blockage nasolacrimal duct } \\
1 \text { Hunter's syndrome } \\
1 \text { jejunal atresia }\end{array}$ \\
\hline
\end{tabular}


TABLE 5 Details of women receiving full vitamin supplementation who produced a hydrocephalic infant.

\begin{tabular}{|c|c|c|c|c|c|}
\hline \multirow[t]{2}{*}{ Patient* } & \multirow[t]{2}{*}{ Previous NTD } & \multicolumn{2}{|c|}{ Vitamins (days) } & \multirow[t]{2}{*}{ Outcome } & \multirow[t]{2}{*}{ Subsequent } \\
\hline & & Preconception & Post-conception & & \\
\hline 1 & 1 spina bifida $(F)$ & 394 & 42 & $\begin{array}{l}\text { Isolated hydrocephalus }(M), \\
\text { vision impairment, } \\
\text { developmental delay }\end{array}$ & \\
\hline 2 & $\begin{array}{l}1 \text { spina bifida occulta and } \\
\text { hydrocephalus (F) }\end{array}$ & 120 & 42 & $\begin{array}{l}\text { TOP, isolated } \\
\text { hydrocephalus (M) }\end{array}$ & $\begin{array}{l}\text { Encephalocele and } \\
\text { microcephaly, TOP }\end{array}$ \\
\hline 3 & $\begin{array}{l}1 \text { spina bifida }(F) \text { (one of } \\
\text { twins: other twin } M \text { with } \\
\text { congenital dislocated hips) }\end{array}$ & 104 & 42 & Isolated hydrocephalus (F) & \\
\hline
\end{tabular}

*Patients 1 and 2: SE England.

Patient 3: Northern Ireland.

TABLE 6 Details of women with recurrence of NTD despite full vitamin supplementation.

\begin{tabular}{|c|c|c|c|c|c|c|c|}
\hline \multirow[t]{2}{*}{ Patient* } & \multirow[t]{2}{*}{ Previous NTD } & \multicolumn{3}{|l|}{ Vitamins (days) } & \multicolumn{3}{|l|}{ Outcome } \\
\hline & & Preconception & \multicolumn{2}{|c|}{ Post-conception } & & & \\
\hline $\begin{array}{l}1 \\
2 \\
3\end{array}$ & $\begin{array}{l}1 \text { spina bifida }(M) \\
2 \text { anencephaly }(M) \\
1 \text { spina bifida occulta, hairy } \\
\text { patch and tail + hemivertebrae (F) }\end{array}$ & $\begin{array}{l}56 \\
78 \\
39\end{array}$ & \multicolumn{2}{|c|}{$\begin{array}{l}70 \\
42 \\
42\end{array}$} & \multicolumn{3}{|c|}{$\begin{array}{l}\text { Anencephaly (M) } \\
\text { Spina bifida (F) } \\
\text { Anencephaly (M) }\end{array}$} \\
\hline 4 & $\begin{array}{l}1 \text { spina bifida occulta, } \\
\text { hydrocephalus (F) } \\
1 \text { isolated hydrocephalus }(M)\end{array}$ & 121 & \multicolumn{2}{|c|}{42} & \multicolumn{3}{|c|}{ Encephalocele and microcephaly (M) } \\
\hline $\begin{array}{l}5 \\
6+ \\
7\end{array}$ & $\begin{array}{l}1 \text { spina bifida }(\mathrm{F}) \\
1 \text { anencephaly }(\mathrm{M}) \\
1 \text { spina bifida }(\mathrm{M})\end{array}$ & $\begin{array}{r}71 \\
132 \\
40\end{array}$ & \multicolumn{2}{|c|}{$\begin{array}{l}42 \\
42 \\
47\end{array}$} & \multicolumn{3}{|c|}{$\begin{array}{l}\text { Closed meningocele (M) } \\
\text { Anencephaly (M) } \\
\text { Lumbosacral myelomeningocele (M) }\end{array}$} \\
\hline \multicolumn{8}{|c|}{$\begin{array}{l}\text { *Patients 1-4: SE England. } \\
\text { Patients 5-7: Northern Ireland. } \\
\text { †Patient diabetic on insulin. }\end{array}$} \\
\hline \multirow{3}{*}{\multicolumn{3}{|c|}{$\begin{array}{l}\text { NTD, and six of the seven recurrences of NTD were } \\
\text { male. } \\
\text { There are relatively small numbers of women who } \\
\text { were partially supplemented, but their results con- } \\
\text { tinue the trend observed in the fully supplemented } \\
\text { group (table } 7 \text { ). There is one recurrence in } 29 \text { in }\end{array}$}} & Patient & Previous NTD & \multicolumn{2}{|c|}{ Vitamins (days) } & Outcome \\
\hline & & & & & $\begin{array}{l}\text { Pre- } \\
\text { conception }\end{array}$ & $\begin{array}{l}\text { Post- } \\
\text { conception }\end{array}$ & \\
\hline & & & 1 & $\begin{array}{l}\text { Spina bifida }(M) \\
\text { (+ affected brother } \\
\text { and uncle) }\end{array}$ & 18 & 28 & $\begin{array}{l}\text { Spina } \\
\text { bifida (F) }\end{array}$ \\
\hline
\end{tabular}

soutb-east England, while there are 0 recurrences in 30 in Northern Ireland. The patient who had the recurrence took the tablets for 18 days preconceptionally and around 28 days post-conceptionally, stopping because she claimed they gave her headaches and constipation (table 8). It is interesting to

TABLE 7 Recurrences of NTD in women receiving partial periconceptional vitamin supplementation in $S E$ England and Northern Ireland.

\begin{tabular}{lrc}
\hline & SE England & Northern Ireland \\
\hline Total pregnancies & 30 & 34 \\
No of twins & 0 & 0 \\
Spontaneous abortion: not examined & 1 & 0 \\
Babies/fetuses examined, no NTD & 28 & 30 \\
NTD & 1 & 0 \\
NTD & 1 & 0 \\
Total & 29 & 30 \\
\hline
\end{tabular}

note that she stopped around the time of closure of the posterior neuropore and she had a fetus with a lumbosacral spina bifida.

In order to examine the effects of small numbers on the results, the figures have been split into their respective cohorts (table 9). The first and second cohorts represent the pregnancies included in the previous two papers ${ }^{12}$ and the third is the latest unpublished set of figures. In all cases, the cohort end was determined in advance, by setting a specific date when the cohort would be closed. Although in the cumulated figures, Northern Ireland has, overall, only one NTD recurrence less than south-east England, a differential effect is evident almost from the outset. In the first cohort, south-east England had one recurrence and Northern Ireland none, and 
TABLE 9 Comparison of results from the three individual cohorts in vitamin supplementation study.

\begin{tabular}{|c|c|c|c|c|c|c|}
\hline & \multicolumn{6}{|c|}{ Cohorts } \\
\hline & $\begin{array}{l}I \\
U S\end{array}$ & $F S$ & $\underset{U S}{2}$ & $F S$ & $\begin{array}{l}3 \\
U S\end{array}$ & FS \\
\hline \multicolumn{7}{|l|}{ SE England } \\
\hline Total pregnancies & 95 & 70 & 81 & 71 & 84 & 79 \\
\hline Twins & 1 & 0 & 2 & 0 & 1 & 0 \\
\hline Spontaneous abortion: & & & & & & \\
\hline $\begin{array}{l}\text { not examined } \\
\text { Babies/fetuses }\end{array}$ & 4 & 5 & 4 & 10 & 5 & 6 \\
\hline examined, no NTD & 87 & 64 & 75 & 60 & 73 & 71 \\
\hline NTD & 5 & 1 & 4 & 1 & $\mathbf{0}$ & 2 \\
\hline \multicolumn{7}{|l|}{ Northern Ireland } \\
\hline Total pregnancies & 125 & 54 & 118 & 100 & 68 & 92 \\
\hline Twins & 3 & 0 & 0 & 0 & $\mathbf{0}$ & 1 \\
\hline $\begin{array}{l}\text { Spontaneous abortion: } \\
\text { not examined } \\
\text { Babies/fetuses examined }\end{array}$ & 8 & 6 & 7 & 8 & 6 & 7 \\
\hline $\begin{array}{l}\text { Baoles/retuses examined, } \\
\text { not NTD }\end{array}$ & 120 & 48 & 111 & 92 & 62 & 86 \\
\hline NTD & 6 & 0 & 6 & 1 & 2 & 2 \\
\hline
\end{tabular}

this 'lead' has been maintained throughout, and is also seen in the PS groups.

\section{Discussion}

Periconceptional vitamin supplementation was associated with fewer recurrences of NTD when compared with no supplementation in both southeast England and Northern Ireland. However, the effect was more marked in Northern Ireland, where there was a 3.6-fold reduction in the overall recurrence risk, compared with a slightly less than twofold reduction in south-east England. Thus, the beneficial effect of vitamin supplementation in the prevention of NTD is less in the lower than in the higher prevalence area.

An interesting finding of relevance to the theory of multifactorial inheritance concerns the sex of the recurrences of NTD which occurred despite full supplementation. There were seven recurrences, of which six were in males. Neural tube defects are normally well known to have a female sex bias. In multifactorial conditions where there is an unequal sex incidence, it is thought that the less frequently affected sex has a greater genetic element in the aetiology. So, just as with population prevalence, it would be expected that the less commonly affected sex would respond less well to environmental therapy. Our findings support the supposition, for our 'failures' are predominantly male. Female fetuses thus appear to be more sensitive than males to environmental manipulation. ${ }^{56}$ This fact is difficult to explain since the neural tube closes before sex differentiation has occurred. However, it parallels exactly what has been found in the mouse mutant curly-tail, an animal model of human NTD with maternally administered environmental agents at the time of neurulation. ${ }^{78}$

The occurrence of three cases of hydrocephalus following full supplementation, a prevalence of $0.71 \%$, was greater than expected. In the combined unsupplemented groups, the prevalence was $0.18 \%$ (one in 543) and in the amniocentesis study of N C Nevin (unpublished data), it was $0.19 \%$ (two in 1012). Cohen et $a l^{9}{ }^{9}$ in a survey of published studies, found that there was a two to five-fold increase in the frequency of hydrocephalus among sibs of NTD probands, with an overall prevalence of $0 \cdot 21 \%$. The significance of the occurrence of infants with hydrocephalus, which has come to light in the latter stages of our study, is not clear. With such small numbers, figures can be distorted by a single case. It now seems that one patient (No 2, table 5) should be excluded from the figures. She presented initially with a previous child with hydrocephalus and spina bifida occulta which was considered to be part of the multifactorial NTD spectrum. Subsequent events suggest, however, that this may not be the case, for she has now also had a fetus with isolated hydrocephalus and another with encephalocele. This pattern, together with other features, is more in keeping with Warburg syndrome, formerly HARD $\pm \mathrm{E}$ syndrome, an autosomal recessive condition. However, even if this patient were excluded from the hydrocephalus total, the prevalence in our fully supplemented women is still higher than expected (two in $422,0.47 \%$ ).

On the matter of exclusions, it is probable that one of the fully supplemented patients who had a recurrence of an NTD should also be omitted from our figures (No 6, table 6), for she is a diabetic on insulin. Several studies have indicated that insulin dependent diabetic women produce more infants with congenital abnormalities including NTD. ${ }^{10} 11$ It has been calculated that anencephaly occurs three times more frequently in infants of insulin dependent diabetic women than in other infants. ${ }^{12}$ Vitamin supplementation is an attempt to manipulate the environmental limb of the multifactorially derived NTD and even this group of NTDs may be heterogeneous. However, vitamin supplementation was not expected to prevent NTD of different aetiologies. When patients first present, all relevant details are not always known, and so, on occasion, women are supplemented whom it later transpires are not really suitable. We feel it important to present data on all our patients who entered the study, but we also consider it legitimate to exclude from the final analysis our two patients who, in retrospect, seem not to have the multifactorial form of NTD. Omitting the patient with Warburg syndrome (south-east England, who had two babies while on 
TABLE 10 Final overall recurrence of NTD in unsupplemented and fully supplemented women in SE England and Northern Ireland following amendment.

\begin{tabular}{|c|c|c|c|c|}
\hline & \multicolumn{2}{|c|}{$S E$ England } & \multicolumn{2}{|c|}{ Northern Ireland } \\
\hline & US & $F S$ & US & $F S$ \\
\hline NTD & 9 & 3 & 14 & 2 \\
\hline $\begin{array}{l}\text { Total } \\
\text { Recurrence }\end{array}$ & $\begin{array}{l}\overline{250} \\
1 \text { in } 28 \\
3.6 \%\end{array}$ & $\begin{array}{l}\overline{196} \\
1 \text { in } 65 \\
1.5 \%\end{array}$ & $\begin{array}{l}\overline{293} \\
1 \text { in } 21 \\
4.8 \%\end{array}$ & $\begin{array}{l}\overline{225} \\
1 \text { in } 112 \\
0.9 \%\end{array}$ \\
\hline
\end{tabular}

supplementation) and the diabetic (Northern Ireland) from the results, the amended overall recurrence for south-east England is three in 196 (one in 65, 1.5\%), and for Northern Ireland is two in 225 (one in 112, $0.9 \%$ ) (table 10 ). This represents a $2 \cdot 4$-fold reduction in the recurrence risk for south-east England and a 5-4-fold reduction in Northern Ireland. Thus, the differential effect of vitamin supplementation between the two areas becomes even greater.

The fact that vitamin therapy does appear to have a lesser beneficial effect in a low prevalence population has some important implications. Firstly, this approach to the primary prevention of NTD might not be worth introducing into some areas, particularly those where the prevalence is less than that of south-east England. Although the prevalence in south-east England is low compared with the rest of the United Kingdom, on a world-wide scale it is not particularly low. It could be that this form of therapy should be recommended for use only in medium to high prevalence populations. Secondly, the results of any future trials assessing the effectiveness of such therapy must take into account the prevalence of the areas involved. If populations are included which have a very low prevalence, then the lesser effects from these may dilute the overall results and mask a truly beneficial effect in the higher prevalence populations.

We feel that our comparative study has yielded some significant data and we consider it important that our study should continue using the established protocol in order to get a substantial body of data not influenced by small numbers. It is salutary to note that if the third cohort of south-east England involving 146 women (73 US, 73 FS) was taken alone, it would appear that not being supplemented is more beneficial than being supplemented.
In south-east England this work was financed ini- $\mathbb{\Phi}$

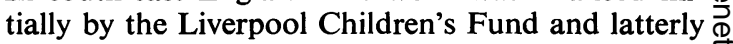
by the Buttle Trust. In Northern Ireland, the work was financed by The Northern Ireland Association $\stackrel{5}{\rightarrow}$ of Spina Bifida and Hydrocephalus and Branches of 0 the Association of Spina Bifida and Hydrocephalus 들 in Belfast, Mid-Ulster, Ballymena, and Coleraine. Beecham Pharmaceuticals have generously supplied $\widetilde{\nabla}$ the tablets throughout. We gratefully acknowledge all this assistance.

\section{References}

1 Smithells RW, Sheppard S, Schorah CJ, et al. Apparent prevention of neural tube defects by periconceptional vitamin supplementation. Arch Dis Child 1981 ; 56:911-8. ì

2 Smithells RW, Nevin NC, Seller MJ, et al. Further $\rightarrow$ experience of vitamin supplementation for the prevention $\mathrm{G}$ of neural tube defect recurrences. Lancet 1983;i:1027- w 31.

3 Sever LE. An epidemiological study of neural tube defects 음 in Los Angeles County. II. Etiologic factors in an area with low prevalence at birth. Teratology 1982;25:323-34.

4 Seller MJ. Recurrence risks for neural tube defects in a genetic counselling clinic population. J Med Genet 1981; 18:245-8

5 James WH. The sex ratio in anencephaly. $J$ Med Genet 1979;16:129-33.

6 Seller MJ. Cause of neural tube defects. J Med Geng 1980;17:491-2.

7 Seller MJ, Embury S, Polani PE, Adinolfi M. Neur tube defects in curly-tail mice. II. Effects of materrfli administration of vitamin A. Proc $R$ Soc Lond [Biof] 1979;206:95-107.

8 Seller MJ. Neural tube defects: cause and prevention. 음 In: Adinolfi M, Benson PF, Giannelli F, Seller MJ, eds. Q Paediatric research. A genetic approach. London: Spastics $\overrightarrow{\vec{B}}$ International Medical Publications, 1982:197-211.

9 Cohen T, Stern E, Rosenmann A. Sib risk of neural tube defect: is prenatal diagnosis indicated in pregnancies following the birth of a hydrocephalic child? $J$ Med Genet 1979;16:14-6.

10 Molsted-Pedersen L, Tygstrup I, Pedersen J. Congenital malformations in newborn infants of diabetic women: correlation with maternal diabetic vascular complications. Lancet 1964 ; i:1124-6.

11 Soler NG, Walsh CH, Malins JM. Congenital malformations in infants of diabetic mothers. $Q J \operatorname{Med} 1976 ; 45$ : 303-13.

12 Mills JL. Malformations in infants of diabetic mothers. Teratology $1982 ; 25: 385-94$.

Correspondence and requests for reprints to Dr Mary $\mathcal{N}$ J Seller, Paediatric Research Unit, 7th Floor, Guy's Tower, Guy's Hospital, London SE1 9RT. 